\title{
A POTENTIAL THEORY-BASED APPROACH OF THE REHABILITATION STRATEGY OF HISTORIC CENTRE OF SIBIU IN A POSTMODERN PERSPECTIVE
}

Guttmann Szabolcs-István ${ }^{1}$

UDK: 719(498.46)

DOI: 10.14415/zbornikGFS23.005

Summary: The historic centre of Sibiu, is an obvious example of the complexity and generosity of the Medieval urban space, well preserved until nowadays. Beyond 'states' and nice 'thoughts' regarding the knowledge of the inherited space, the documentations and the urban renewal projects received in Sibiu a deadline '2007'. The 'action' of testing and applying the complex renewal strategy make the historic centre of Sibiu the first postmodern model in Romania. Patrick Geddes diagrams regarding the theories of urbanism and real life can be an efficient working tool, even in the urban renewal area, in order to check the proposed strategies, respectively for the actual successes made in this field. Geddes's diagram shows the evolution of the built frame in the circle of life, ACTS through FACTS and THOUGHTS to DEEDS. Therefore, we propose a theoretical overview of the renewal methods of the Spirit of the Place (Genius Loci) in Sibiu.

Keywords: Urbanism, Patrick Geddes diagrams, the Spirit of the Place, postmodern perspective, interdisciplnarity.

\section{THE HISTORIC CENTRE OF SIBIU IN THE POSTMODERN AGE IN THE LIGHT OF PATRICK GEDDES' DIAGRAM}

As early as 1910 the Scottish botanist Patrick Geddes ${ }^{2}$ managed to synthesize in a diagram entitled "Notation of Life" the essential framework conditions of the interactions between man/folk, work and place. It is, however, true that because of the radical urban planning conceptions of modernism, these ideas had not reached professional consciousness before the 1970s. He took as a landmark the work of Frédéric Le Play "Les ouvriers Européens" published in Paris in 1864, in which place, work and family are presented as basic elements of society. Patrick Geddes is one of those who through their work built bridges between past and present, between matter and life, between science and art, being one of the few specialists who tried to comprehend the whole in a synthesizing vision. In 1920 he founded a town planning department in Bombay (India), understanding in equal measure the structure of settlements in India, Europe or America. Geddes's diagram shows the evolution of the built environment in the spiral of life, passing from ACTS through FACTS and THOUGHTS to DEEDS.

\footnotetext{
${ }^{1} \mathrm{PhD}$ candidate at the "Lucian Blaga" University (Sibiu), guttmann61@gmail.com

${ }^{2}$ Patrick Geddes' theory illustrated by the diagram has been translated to Hungarian in the collection of urban planning studies edited by Ferenc Vidor published by Gondolat in Budapest in 1979, pp. 110-115.
} 


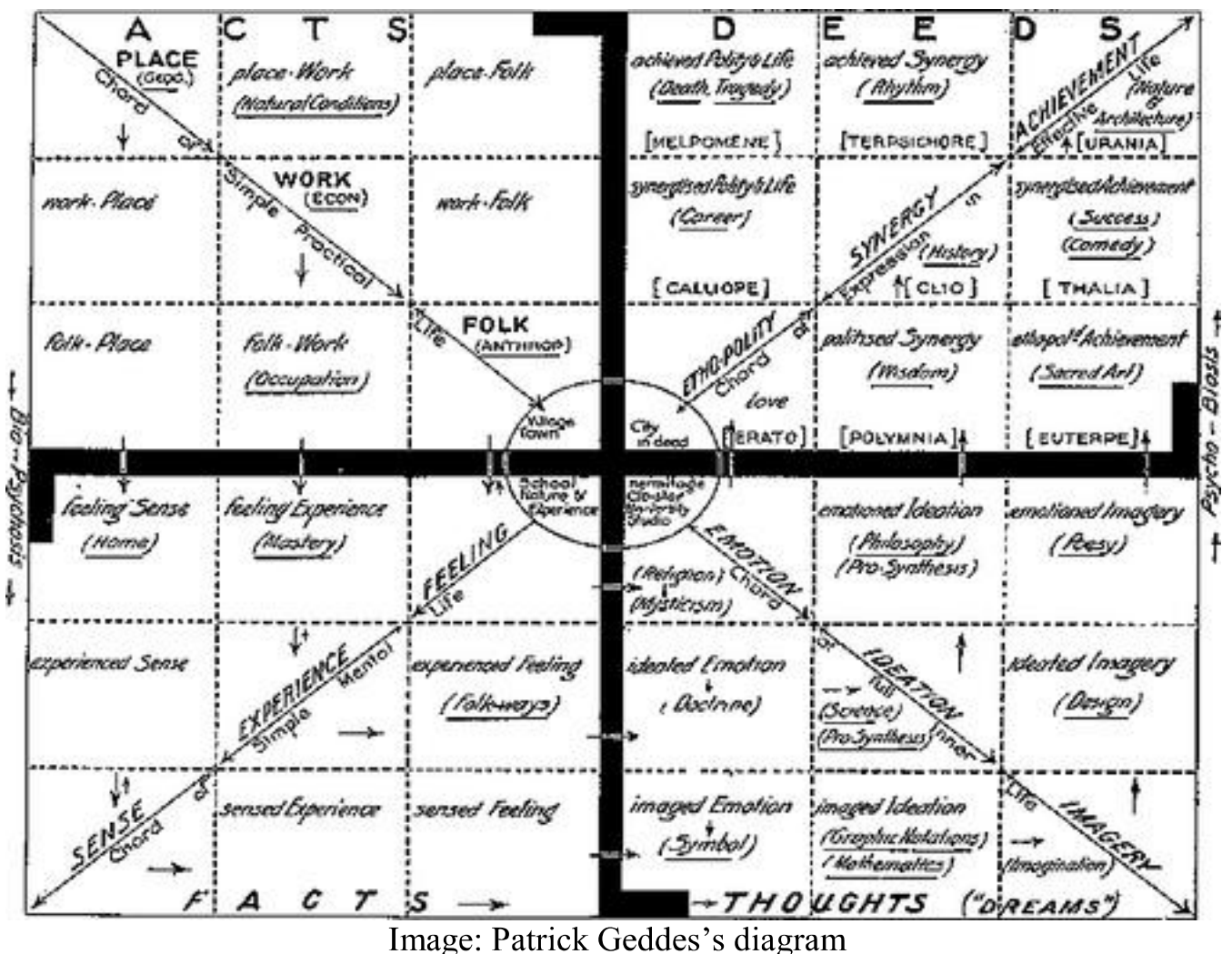

"Normal. Sibiu. Young since 1191" was the slogan of 2007, when the historical center of Sibiu was the main scene of the events of the European Cultural Capital. The revival of urban life in this area became a reality. Through a new infrastructure, with facilities placed underground and the rearrangement of the urban area by marking the sites of archaeological value, a balance of "facts" and "deeds" has been established in the public domain. By rethinking the traffic system and restoring buildings serving mixed functions, private and public, representative for this area - cultural, administrative, commercial and of services - "thoughts" have became real "acts". In the future this cycle from "facts to acts" through ,deeds" and wise "thoughts" about the appreciation and balanced use of inherited areas only has to be perpetuated. The year 2007, of Sibiu as the European Capital of Culture may stand for that part of the "charting of life" by Patrick Geddes which presents "real life" with nine theoretical segments, each one having its own ancient patron muse. Through the revival of these European mythological/artistic roots, Geddes' ideas receive an additional historical endorsement. The three basic elements: people-anthropology, work-economy, geographical locationgeography, derived at the level of "real life" may be found in the people who constitute the "ethics of the universal order" of love (in ancient times the muse Erato, in Sibiu ecumenical multiconfessionalism), in interdisciplinary scientific work, meaning "synergy" (the ancient muse Clio, in Sibiu the values of multiculturalism), and in urbanized geographical location, meaning the "perfection of created space" (in antiquity the muse Urania, in Sibiu the resurrected historic centre). The combination of the three elements, two by two, gives birth to six more muses, thus establishing an ancient

\section{8 | ZBORNIK RADOVA 23 (2013) |}


logic of balance in the presence of the nine Muses, who may watch over the "acts" of urban actors in the present, too.

Euterpe, resulting from the combination of Erato and Urania sanctifies creation, protects the fulfillment of the ethics of universal order, birth, population conditioned by place (the opening of events).

Melpemone, resulting from the combination of Urania and Erato, symbolizes perfect universal order, death and personal tragedy (finishing of events).

Polyhymnia, resulting from the combination of Erato with Clio, ensure universal order based on synergy, wisdom (the celebration of cultural events).

Calliope, resulting from the combination of Clio and Erato, keeps her eye on universal order and individual life, the road of life (celebration of sacred events).

Terpsychore, resulting from the combination of Urania and Clio, symbolizes perfect synergy, rhythm as a source of revitalizing the built environment (the search of the Genius Loci).

Thalia, resulting from the combination of Clio and Urania, sanctifies synergy of perfection and success, as the aim of rehabilitation (retrieval of the Genius Loci).

It is possible to analyze through this concept the whole city or just one representative area at once. The complexity of the historical center of Sibiu lets us extrapolate these ideas to smaller urban islands, squares or streets. The presence of the nine Muses symbolizing wholeness is easy to observe even in the case of the first enclosure of the fortress: the Huet Square. Erato materializes in the Lutheran Cathedral, formerly Saint Mary Church, Euterpe and Melpemone sanctify this place through the baptistry in the sanctuary and through the tombstones in the church ferula. Clio is present in the school building, Polyhymnia and Calliope mark the school itself and the acquired knowledge through which the germ of public space becomes the head of the line on the journey of life (the natives of Sibiu started generally from here and return here, up to this day, for rememoration). Urania is the line of fortification that gave concrete form this urban space. Terpsychore and Thalia are the catalysts of rehabilitation, revival and reproduction of creative energy in the context created by the seven muses before them.

\section{INTERVENTIONS IN PUBLIC SPACES AND ON PUBLIC BUILDINGS IN THE HISTORIC CENTRE OF SIBIU}

Why here? How? For whom?

We should seek for multiple answers to these questions conditioned by place (Urania), synergistic effort (Clio) and the inheritors of the place (Erato) in the light of postmodern ideas to revive the Spirit of the Place, more exactly, the raising of awareness about, relocation or revival of this Spirit? Can this built context blend the Spirit of Contemporary Time with the Holy Historic Spirit, which has generated an urban texture subordinated to the accents of the places of worship? What did the cultural tourist understand of the efforts of self-representation in 2007? Let us consider from this angle the urban spaces, together with the public institutions of reference in the service of contemporary life in the historical center of Sibiu. The Huet Square with the Lutheran Cathedral, the Brukenthal High School, the Lutheran Parish House, the workshops and 
dormitories of travelling journeymen are the most important testimonies about the core of the medieval "Holy Spirit" of the place ${ }^{3}$.

The Small Square lined with porched houses along the two enclosures of fortifications in convex shape in the first enclosure and in concave shape in the second one - gives place to certain representative institutions as regards "Renaissance Spirit", that is, social life. The Luxembourg House - no.16 - the catalyst of events in 2007, the Museum of Universal Ethnography "Franz Binder" together with the Documentation Center "Cornel Irimie" and the film studio of the Centre for Documentary, Anthropological Research, ASTRA - under-nr.11 and 12 - bring to the foreground anthropological cultural values. The "Emil Sigherus" Museum, - no. 20 and 21 - after derestoring the interventions of the 1970s (when it served as the House of Arts), in 2006 its ground floor level was restored, hosting now representational workshops of traditional crafts. The Museum of Pharmacy - no. 26 - offering insight in the history of healing human disease, was refurbished in the 70's, and displays an authentic interior. Since 2003, the Sibiu Branch of the University of Architecture and Urbanism in Bucharest - no. 22 - (moved in 2012) has represented this idea of "pharmacy" in the field of architecture, through its restoration department. This "Renaissance spirit" is supported by many exceptional restaurants and cafés in the area.

The Large Square, with an area of about 15,000 square meters, highlights the "Spirit of the Time" by monumental architectural creations, the expression of CounterReformation and Baroque pomp together with urban interventions dating from the $19^{\text {th }}$ $20^{\text {th }}$ and $21^{\text {st }}$ century. The north side of the Large Square bears the imprint of the forms of representation of these powers. The Council Tower, the symbol of civil jurisdiction in the Middle Ages, is the centre of reception and representation of the city today with seven levels of exhibition spaces and the last, belvedere level. The Jesuit Church and School are representative monuments of religious restoration, since the new wave of Austrian Roman Catholic domination left behind a new fingerprint of cultural evolution. This was the place where also Gheorghe Lazăr, the founder of the first Romanian language school was educated. He is commemorated with a new bronze statue in front of the building. In the church masses are held in four languages: Latin, German, Hungarian and Romanian. A multifunctional cultural space called "Habitus" was inaugurated in 2008 under the above mentioned church (in the former mortuary chapel of about 450 $\mathrm{m}^{2}$ ), funded inclusively by private donations, and it is dedicated to events that keep lit

\footnotetext{
${ }^{3}$ The core of the city of Sibiu is still to found in the buildings and public, semipublic spaces of the Huet Square. Hermann's village, in the early Middle Ages set along the line of the current street May 9, survived sieges due to its fortified church built on top of the hill. This area, consisting of the Romanesque church, the parsonage, the school and the village cemetery, was then the spititual space and last refuge of the village. Similar variants of this functional configuration have been preserved up to this day in many Saxon villages with fortified churches in the area, such as the villages Biertan, Bazna, Agârbiciu, Hosmann or Alțâna. The examples are more numerous, but what is important for understanding the motives that led to the development of the Sibiu ensemble is the presence of the large plateau to the south-east of the church, where the surface of an entire early medieval town with spacious streets, squares and spaces for public activities could be surrounded by fortified walls. The first fortified enclosure has remained the urban expression of the germ of spiritual life, with the accent of the church bell tower, surrounded by the "protective shell" of perimetral fortifications composed of walls and the first tower gate to the West, the parsonage to the north, the row of dwelling houses from eastern direction and the ensemble of the medieval school, currently the Brukenthal school to the south. The volume of the tower and church are located at a decentered position with respect to the enclosure, pulled slightly to the northwest. So this urban mini-ensemble represents the synthesis of organic architectural compositions with multiple spatial meanings.
} 
the flame of the "Holy Spirit" blended with the "Spirit of the Time", immortalizing the "Spirit of the Place". The journey of the location of the City Hall starting in the postwar period until its return to this square in august 2006 is worth mentioning. The building was constructed in 1906 as the headquarters of the Land Bank, after 1944 it was nationalized, and the City Hall, together with the leading party organization came to be the new beneficiaries. In the 70s the building was abandoned by these institutions, because of the new status of the city, which, as a county capital city claimed for larger offices. There have been several attempts at building a new city hall, or a new administrative center. One of these projects proposed the demolition of the Hecht house in the Large Square, the present headquarters of the Democratic Forum of Germans in Romania. Another more determined idea supported the construction of a new center with a fifteen-storey administrative building instead of the Barracks 90. This project was carried out only partially, by demolishing the Baroque building located on the former Cisnădie Gate Bastion in 1986. After 1990 these ideas were reviewed and each institution started its own lobbying. The new city hall was constructed until 2000 to the unfinished "gray stage", in the current location of the Ramada Hotel. In 2001, in accordance with the newly outlined strategy of the local government, which proposed the sale of the unfinished construction, and the investment of the value obtained in the restoration and reconversion of the former Land Bank, turning it into a representative City Hall. In 2002 the transaction was carried out, so that between 2003-2006 restoration was also successfully completed. In the present, the ground floor of the building hosts the Tourist Information Centre as well as the Information Centre for Citizens coupled with the new multifunctional space of the atrium built in the place of the interior service courtyard. Each floor has now a meeting/conference room in order to facilitate the organization of events, inclusively the extra-administrative programs. The opening of an interior restaurant in a basement was proposed, but it has not yet been finalized. It seems that through these measures and new functions served successfully the rehabilitation of the presence of local government in the historic center. The "Spirit of Place" thus has a new representative space in a historic public building, in an exceptional location linked intimately to the Large Square, the Small Square and the Brukenthal street, actually located on the former alignment of the fortification walls of the second enclosure. The link between the two squares is ensured in fact by this rehabilitated building. Instead of the fortification wall the new skylight of the central atrium produces that polarizing public space, which provides the institution with its current meaning. As regards volumetry and architectural decoration, the building is the youngest "intruder" in the environment of the historic urban core. The bank façades overloaded with stucco decorations, criticised in 1906, especially in comparison with the more sober neighbourhood, are "used" today as common good, an architectural accent that attracts visitors into the building. Basically the building may be seen as a public information pocket of the Large Square between the Brukenthal Palace and the Roman Catholic Church. The Brukenthal Museum is the Baroque palace that served as the residence of the governor of Transylvania, Samuel von Brukenthal, in 1787, and then became the first private museum open to the public at the beginning of the $19^{\text {th }}$ century. This public function has saved the building from transformation and devastation at the time of nationalization. The presence of this significant museum collection catalyzed the cultural life of the city, and iy has been functioning as an exceptional museum complex from as early as the difficult period of the 1950-1980s. 


\section{PROPOSAL FOR WORLD HERITAGE LISTING VERSUS EUROPEAN CAPITAL OF CULTURE 2007}

Preparations for the status of European Capital of Culture 2007, focused primarily on the revitalization of nodal points in the the historic center. The arguments supporting urban values in the nomination documentation proposing the inclusion of this ensemble on the World Heritage list, referred to the whole medieval stronghold, together with an area of similar size around the protected area to be placed under protection. Although, at first sight, the two strategies have much in common as regards the promotion of the historic center in an international context, the actual results being in favor of 2007. The exceptionality of Sibiu, in both cases, derived from outstanding local capacity to support these efforts financially and logistically.

In the process of obtaining the title of European Capital of Culture 2007, Sibiu had a special history in comparison with its predecessors, being the first city elected in this partnership from beyond the borders of the EU. The documents required for argumentation concerning effective capacity, in February 2004, were submitted solely through the efforts of a local association, the founding members coming from the local government and the cultural institutions and associations of the city, called "Association Sibiu European Cultural Capital 2007". The most important element of this endeavour was the possibility of accessing a strategy by deviating from the rule, but in a well grounded manner, in the light of the new unionist vision formulated by the management team in Luxembourg. Without this "spark" of logistics, through which the entire region of Luxembourg together with Sibiu was promoted as extended European Cultural Capital in 2007, in a positivist vision of multiethnicism, multiculturalism and multiconfessionalism. Sibiu not only did not have the chance to promote these values on an international scene, but had no political and social justification for arguing for these necessary rehabilitation efforts locally. Co-optation in the interest of all inhabitants, despite major social changes from an ethnical and numerical point of view, transformed the historic centre not only into a protected zone but also into a representative area. Historical central squares became again the catalyst spaces of urban life, the "living room and guest room" of the whole city.

The documentation submitted to UNESCO in September 2005, asking for the inclusion of the historical center of Sibiu on the World Heritage list, was also carried out through local effort, funded by the municipality and elaborated by the Sibiu branch of the Romanian Academy, under the direction of the Academician and Doctor of Architecture Paul Niedermaier. The outcome of the undertaking is, however, still uncertain, due to new regulations of UNESCO in the new millennium, regarding the "balance" of nominations accepted according to continents. As it is well known, sites and cultural testimonies from Europe have become prevalent in this respect, therefore there is little chance to introduce the historic center of Sibiu among distinguished sites. In conclusion we may state that a similar lobbying approach as in the case of European Capital of Culture project is necessary. Either opting for a novel, exceptional form of nominating this valuable site individually, or rather, as an exceptional emanation of a group of values, together with such a group, in a similar way as in the case of the association of the multicultural values of the Luxembourg region with Sibiu. Despite these logistical inconsistencies, we could notice undeniable benefits of the elaboration of this documentation as regards the raising of awareness and promotion of this segment of 
cultural heritage both locally and on an international level. It still serves as a testimony, a medium- and long-term framework document of the efforts aimed at the conservation and reintegration of the historical center into the contemporary city. If we refer back to the diagram of Geddes, we could argue that the evolution of the built environment in the spiral of life, from through ACTS through FACTS and THOUGHTS to DEEDS, in the historic center of Sibiu was accompanied on both levels by a remarkable effort, "deeds" having been actually transposed into synthetic "thoughts" at the highest level of the international nomination documentation, and "facts" have become "acts" at European level due to the events in 2007.

\section{BIBLIOGRAPHY}

[1] ALEXANDRU, Sorin, Identitate în ruptură, Mentalităţi româneşti postbelice, Editura Univers, Bucureşti, 2000.

[2] BABIAS, Marius, Subiectivitatea- marfă. O povestire teoretică, Cluj, Editura Idea Design\& Print,2004.

[3] DERER, Hanna, Sibiu:Arhitectura în Epoca Barocă, Editura Universitară „Ion Mincu" București, 2003.

[4] COMPAGNON, Antoine, Cele cinci paradoxuri ale modernităţii, Cluj, Echinox, 1998.

[5] FABINI, Hermann şi Alida, "Sibiu" portretul unui oraş din Transilvania, Editura Monumenta, 2001.

[6] HUTCHEON, Linda. Politica postmodernismului, Bucureşti, Editura Univers, 1997.

[7] LYONARD, Jean-Francois. Condiţia postmodernă, Cluj, Editura Idea Design\& Print, 2003.

[8] MOLDOVAN, Mircea, Istoria artei contemporane, Editura U.T.PRES, ClujNapoca, 2002, "Patru decenii de artă care au schimbat lumea noastră:1960-2000".

[9] NIEDERMAIER, Paul, Städtebau im Mittelalter. Siebenbürgen, Banat und Kreischgebiet (1242-1347), Köln Weimar Wien, 2002.

[10] SEBESTYÉN, Gheorghe, O pagină din istoria arhitecturii României. Renaşterea, Editura Tehnică, Bucureşti, 1987.

[11]STĂNCIUGELU, Irina, Prefixul "post" al modernităţii noastre, Editura Trei, București, 2002.

[12] VIDOR, Ferenc, Urbanism, -studii urbanistice traduse în limba maghiară-, Editura Gondolat, Budapesta, 1979.

\section{POTENCIJALNI, NA TEORIJI BAZIRAN PRISTUP STRATEGIJE REHABILITACIJE ISTORIJSKOG CENTRA SIBIJUA U POSTMODERNOJ PERSPEKTIVI}

Rezime: Istorijski centar Sibijua je očigledan primer složenosti $i$ velikodušnosti srednjevekovnog urbanog prostora koji se dobro očuvao do danas. Izvan "stanja" $i$ lepih "misli" vezanih za znanje o nesleđenom prostoru, dokumentacija i projekti urbane 
obnove Sibijua morali su biti završeni do 2007. godine. „Akcija” testiranja i primene kompleksne strategije obnove načinila je od istorijskog centra Sibijua prvi postmoderni model u Rumuniji. Dijagrami Patrika Gedesa koji se odnose na teorije urbanizma i realnog života mogu biti efikasno oruđe, čak $i$ u zonama urbane obnove, da bi se proverile predložene strategije, odnosno aktuelni uspesi ostvareni na ovom polju. Gedesov dijagram pokazuje evoluciju izgrađenog okvira u životnom ciklusu, DELOVANJE kroz CINJENICE i MISLI do OSTVARENJA. Zbog toga predlažemo teorijski pregled metoda obnove Duha mesta (Genius Loci) u Sibiju.

Ključne reči: Urbanizam, dijagrami Patrika Gedesa, Duh mesta, postmoderna perspektiva, interdisciplinarnost. 